\title{
PENGGUNAAN BUKU TEKS MATEMATIKA: STUDI KASUS MAHASISWA PENDIDIKAN MATEMATIKA UNIVERSITAS KUNINGAN
}

\author{
oleh \\ ${ }^{1)}$ Mohamad Riyadi, M.Si., ${ }^{2)}$ Nunu Nurhayati, M.Pd., \\ ${ }^{3)}$ Nuranita Adiastuty, M.Pd., ${ }^{4}$ Heru Haerul Anwar \\ Program Studi Pendidikan Matematika, Universitas Kuningan, Jawa Barat. \\ ${ }^{1)}$ mohamadriyadi2208@ gmail.com ${ }^{2)}$ nunu.nurhayati.9@gmail.com \\ 3) anitha_dyaz2@yahoo.co.id
}

\begin{abstract}
Abstact
Textbooks have an important role in the learning process. In addition as a reference material, also have the potential to affect student learning. In this study, carried out a survey of mathematics education students. Students were asked to describe how they used textbooks. The survey was conducted by giving questionnaires and interviews about what components are used, when students look at each component, the reason for these components as well as the students see what difficulties encountered when used textbook. Data collected was processed using descriptive statistics as well as to determine there are differences in the use of good text books for each component or components in pairs using Cochran's Q test and McNemar Test. The result show that students tend to use the sample chapter to build their understanding of math concept than the chapter text description. Difficulties experienced when students understand basic concepts such as definitions and theorems which causes difficulty in working on.
\end{abstract}

Keyword: Textbooks, Component of Textbooks, Mathematics Education Student

Abstrak
Buku teks mempunyai peranan penting dalam proses pembelajaran. Selain sebagai
bahan referensi, juga mempunyai potensi untuk mempengaruhi pembelajaran
mahasiswa. Dalam penelitian ini, dilakukan survei terhadap mahasiswa program
studi Pendidikan Matematika. Mahasiswa tersebut diminta menggambarkan
bagaimana mereka menggunakan buku teks. Survei dilakukan dengan memberi
angket dan melalui wawancara mengenai komponen apa saja yang digunakan, kapan
mahasiswa melihat tiap komponen, apa alasan mahasiswa melihat komponen
tersebut serta kesulitan apa yang dihadapi ketika menggunaka buku teks. Data yang
terkumpul diolah menggunakan statistika deskriptif serta untuk mengetahui apakah
terdapat perbedaan penggunaan buku teks baik tiap komponen atau komponen
berpasangan menggunakan uji Cochran's Q dan uji McNemar. Hasilnya


menunjukkan bahwa mahasiswa cenderung menggunakan bab contoh untuk membangun pemahaman mereka mengenai konsep matematika dibanding dengan bab penjelasan teks. Kesulitan mahasiswa dialami saat memahami konsep dasar seperti definisi dan teorema yang mengakibatkan kesulitan dalam mengerjakan soal.

Kata Kunci: Buku Teks, Komponen Buku Teks, Mahasiswa Pendidikan Matematika

\section{PENDAHULUAN}

Pembelajaran pada mahasiswa tidak lepas dengan adanya peran dari buku teks, khususnya buku teks matematika. Shepherd (2005) mengemukakan bahwa mahasiswa yang menggunakan panduan yang terstruktur dalam membaca buku teks matematika lebih berpartisipasi di kelas, menyelesaikan lebih banyak tugas dan menjaga kehadiran. Shepherd menambahkan bahwa membaca buku teks matematika menciptakan independent learner.

Lebih jauh, bila ditinjau dari sifat dasar buku teks matematika, yaitu penjelasan, contoh-contoh dan berbagai penerapan, buku teks matematika memberi harapan agar mahasiswa membaca buku teks. Sifat dasar buku teks dituangkan dalam atribut/fitur buku teks yaitu struktur dan organisasi buku, format penyajian yang mencakup warna, tipe dan ukuran font, ilustrasi, isi, contoh, dan lain-lain. Atribut/fitur buku teks dapat mempengaruhi ketertarikan mahasiswa secara positif atau negatif dan akibatnya mempengaruhi sikap mahasiswa tersebut. Studi tentang hal ini menyatakan bahwa terdapat korelasi positif antara atribut/fitur buku teks dan sikap mahasiswa terhadap matematika (Afolabi \& Animasahun, 2013).
Beberapa penelitian mengenai penggunaan buku teks menyatakan bahwa penggunaan buku teks pada mahasiswa teknik tingkat pertamasangat rendah (Randahl, 2012) dan mempunyai pemahaman yang terbatas terhadap simbol-simbol matematika (Sastre Vazquez, et.al, 2012). Selain itu, mahasiswa cenderung menggunakan bagian contoh daripada bagian penjelasan (Weinberg. et.al, 2012).

Pada penelitian ini akan ditinjau cara mahasiswa berinteraksi dengan buku teks matematika. Yaitu mengetahui sejauh mana tingkat penggunaan buku teks matematika pada mahasiswa pendidikan matematika sesuai dengan alur buku teks, khususnya, komponen apa saja yang digunakan, kapan mahasiswa melihat tiap komponen, apa alasan mahasiswa melihat komponen tersebut serta kesulitan apa yang dihadapi mahasiswa pendidikan matematikadalam penggunaan buku teks.

\section{Kajian Pustaka}

\section{Buku Teks Matematika}

Menurut Johansson (2005), buku teks matematika dapat dipandang dari dua sudut pandang. Pertama, buku teks matematika sebagai artefak. Hal ini 
mengandung pengertian bahwa buku teks matematika merupakan hasil karya manusia yang melestarikan dan mewariskan pengetahuan dalam sistem pendidikan. Namun, peran buku teks dalam sistem pendidikan tidak mudah ditetapkan. Buku teks dapat dianggap sebagai sarana pembelajaran yang penting atau menjadi rintangan dalam pengembangan sistem pendidikan. Kedua, buku teks sebagai instrumen. Hal ini fokus hanya pada skema pemanfaatan buku teks. Baik pemanfaatan oleh pengajar maupun peserta didik.

\begin{tabular}{rcr} 
Buku & teks & \multicolumn{2}{r}{ matematika } \\
merupakan & usaha utama & dalam \\
pengajaran & matematika & dan
\end{tabular}
mempunyai potensi untuk menjadi alat yang sangat berpengaruh untuk membantu mahasiswa mengembangkan pemahaman matematika (Weinberg \& Weisner, 2010). Menurut Weinberg \& Weisner (2010), penelitian di beberapa negara menunjukkan bahwa buku teks berfungsi sebagai "vehicles" yang membuat mahasiswa berinteraksi dengan matematika, sebagai sumber referensi untuk pengajar dan menjadi jalan untuk meneliti perbaikan kurikulum bahkan perbedaan buku teks bisa mempengaruhi capaian pembelajaran mahasiswa.

Fitur yang menarik perhatian dari buku teks matematika, khususnya untuk pengantar matematika mahasiswa S1, adalah keseragaman struktur organisasi buku teks tersebut. Keseragaman ini menimbulkan keseragaman dalam cara bagaimana buku teks yang dimaksud itu digunakan. Lebih lanjut, penulis sering membuat maksud yang jelas agar mahasiswa membaca buku teks dengan cara tertentu (Weinberg, et. al, 2012). Sebagai contoh, Varberg, Purcell \& Rigdon memberi saran kepada mahasiswa sebagai berikut:

Concepts Review Problems To encourage students to read the textbook with understanding, we begin every problem set with four fill-in-the-blank items. These test the mastery of the basic vocabulary, understanding of theorems, and ability to apply the concepts in the simplest settings. Students should respond to these items before proceeding to the later problems. We encourage this by giving immediate feedback; the correct answers are given at the end of the problem set. These items also make good quiz questions to see whether students have done the required reading and have prepared for class.

\section{Gambar. 1}

Fitur yang menarik perhatian dari buku teks matematika (Saran Varberg, Purcell \& Rigdon)

Menurut (Weinberg, et. al, penulis menginginkan pembaca 2012), kutipan ini menyoroti sebuah membaca dengan cara tertentu, tapi penekanan antara maksud penulis/buku dan kecenderungan yang dirasakan oleh mahasiswa. Yaitu, pembaca kemungkinan besar tidak melakukannya. 
Menurut Stray, dalam Johansson (2005), menekankan bahwa hal ini menunjukkan buku teks merupakan jenis buku khusus karena buku tersebut dimaksudkan untuk digunakan dalam pendidikan. Buku teks dirancang untuk menyajikan versi buku pedagogik yang mempunyai sifat pengaruh dalam bidang pengetahuan.

Eco, dalam Weinberg, et. al (2012) memandang buku teks sebagai a closed text, yaitusebagai salah satu usaha untuk memperoleh sebuah "precise response" dari pembaca pada setiap tahap sepanjang "jalur yang dibentuk sebelumnya" (preconceived path).Weinberg, et. al (2012) mengemukakan pendapat Love \& Pimm (1996)bahwa semua buku teks matematika pada dasarnya tertutup dan komponen buku teks matematika khusus, seperti penjelasan, contoh, dan latihan, bertindak sebagai "alat yang digunakan untuk mengatur kerja pembaca dengan buku teks".

\section{Framework Buku Teks Matematika}

Weinberg, et. al (2012) mengembangkan sebuah frameworkuntuk menggambarkan penggunaan buku teks mahasiswa dalam unsur-unsur komponen terstruktur buku teks dan faktor-faktor yang mempengaruhi penggunaan buku teks tersebut.

\section{a. Komponen Buku Teks}

Deskripsi komponen buku teks dihasilkan dari survei terhadap buku teks yang digunakan mahasiswa. Buku yang disurvei antara lain Anton \&
Rorres (2005) dan Varberg, Purcell \& Rigdon (2007). Komponen buku teks tersebut antara lain:

1) Pendahuluan, ditempatkan di awal setiap bab. Komponen ini menggambarkan isi yang akan dibahas, motivasi dan gambaran hubungan dengan topik lain.

2) Penjelasan teks, memuat penjelasan dan inti isi bukudefinisi, teorema, prosedur, rumus, penjelasan bagaimana tiap bagian ini berhubungan dengan topik lain.

3) Contoh, sering dicantumkan di teks bab sebelum soal-soal.

4) Soal-soal, biasanya dimasukkan setelah teks bab dan contoh. Bagian ini dapat dikerjakan menggunakan ide dan teknik yang dijelaskan dalam teks bab dan sering sama dengan contoh.

5) Ringkasan, sebuah ikhtisar/ulasan singkat dari inti isi buku yang dimasukkan di bagian akhir bab. Umumnya berisi daftar unsur, ungkapan atau pertanyaan yang mahasiswa bisa menggunakannya untuk mengulas bab.

6) Jawaban soal/solusi manual, sering dimasukkan di akhir buku teks, berisi jawaban singkat soalsoal atau skema singkat bagaimana menyelesaikan soal.

\section{b. Tujuan dan Situasi Kondisi}

Jika komponen buku teks dipandang sebagai tahap kemajuan mahasiswa, maka konteks yang mana mahasiswa menggunakan tiap komponen juga penting. Untuk mencapai hal itu, diturunkan beberapa 
tujuan dan situasi kondisi selama mahasiswa menggunakan buku teks. Beberapa tujuan yang berpotensi menjadi alasan ketika menggunakan tiap bagian buku teks di antaranya:

1) membaca untuk pemahaman

2) memahami dan memeriksa definisi dan teorema

3) meringkas teks

4) membaca tugas untuk melihat ide yang paling sering muncul

5) menggunakan jawaban latihan untuk memeriksa tugas

6) menggunakan soal dan jawaban latihan yang ekstra untuk memeriksa pemahaman dari soal yang diberikan

7) membaca atau menyalin tugas untuk melengkapi tugas

8) mencari jawaban tanpa pemecahan masalah.

Sedangkan situasi yang mana mahasiswa menggunakan buku teks di luar kelas perkuliahan di antaranya persiapan sebelum perkuliahan, mengerjakan tugas dan belajar saat menghadapi ujian.

\section{c. Pengaruh Potensial Lain pada Penggunaan Buku Teks}

Keyakinan mahasiswa tentang matematika berpengaruh terhadap bagaimana mereka ikut serta dalam aktivitas matematika (Schoenfeld, 1992, sebagaimana dikutip Weinber, et. al, 2012). Dengan demikian, selain desain buku teks, keyakinan mahasiswa-yang digambarkan dalam kualitas mereka menilai suatu buku teks juga berpengaruh terhadap penggunaan buku teks. Berdasarkan pendapat Schoenfeld (1992) dan Llyod
\& Behm (2002), sebagaimana dikutip Weinberg, et. al(2012), keyakinan mahasiswa terhadap penggunaan buku teks antara lain:

1) Buku teks harus menjelaskan "ide besar" perkuliahan.

2) Buku teks harus menjelaskan "konsep pokok" permasalahan.

3) Buku teks harus memberikan contoh untuk menjelaskan materi.

4) Buku teks harus memberikan contoh yang bisa digunakan untuk menyelesaikan soal.

5) Buku teks harus menyoroti persamaan dan definisi penting.

Weinberg, et. al(2012) juga menyatakan bahwa pengaruh lain yang dipertimbangkan terhadap penggunaan buku teks yaitu pengaruh dari dosen dalam pemberian tugas dan perkuliahan. Kategori dalam framework ini adalah

1) Cara dosen meminta mahasiswa menggunakan buku teks.

2) Tingkat penggunaan buku teks dalam kuliah.

\section{METODE PENELITIAN PendekatanPenelitian}

Penelitian ini menggunakan kombinasi pendekatan kuantitatif dan kualitatif untuk lebih memahami penggunaan buku teks matematika. Metode yang digunakan adalah metode survei, yaitu metode yang digunakan untuk mendapatkan data dari tempat tertentu yang alamiah (bukan buatan), tetapi dilakukan perlakuan dalam pengumpulan data, yaitu mengedarkan angket, wawancara, dan sebagainya (Sugiyono, 2010). 
Waktu dan Tempat Penelitian

Penelitian ini dilaksanakan pada April 2016 s.d. Desember 2016. Untuk survei dilaksanakan selama akhir sesi kelas normal di semester genap. Penelitian dilaksanakan di program studi Pendidikan Matematika.

\section{Subjek Penelitian}

Subjek dalam penelitian ini adalah mahasiswa tingkat I, II dan III yang terdaftar pada program studi. Pada tingkat I, II dan III di semester genap,mahasiswatersebut

mengambilmata kuliah Kalkulus 2, Struktur Aljabar dan Statistika Matematika.

Semua mata kuliah yang dipilih untuk survei memerlukan buku teks. Penelitijuga melibatkan dosen pengampu tiap mata kuliah. Peneliti meminta mahasiswa dan dosen menjalankan semua survei dengan sukarela.

\section{Tahapan Penelitian}

a. Tahap Persiapan Penelitian

Pertama peneliti menyusun pedoman wawancara dan angket yang disusun berdasarkan indikator penggunaan buku teks mahasiswa.

b. Tahap pelaksanaan penelitian

Peneliti mengumpulkan data mengenai jumlah mahasiswa yang terdaftar di program studi di mana tempat penelitian dilaksanakan. Setelah jumlah mahasiswa ditentukan, dilakukan survei melalui wawancara, angket dan observasi sesuai dengan waktu yang dijadwalkan. Selanjutnya peneliti melakukan analisis data dan interprestasi data sesuai dengan langkah-langkah yang diterangkan pada bagian teknik analisis data. Untuk menganalisis keabsahan datadilakukan analisis triangulasi terhadap hasil wawancara, angket dan observasi. Setelah itu, peneliti membuat kesimpulan.Peneliti jugamemberikan saran-saran untuk penelitian selanjutnya.

\section{Teknik Pengumpulan Data dan}

\section{Analisis Data}

Dalam penelitian ini, penelitimenyesuaikan dengan teknik pengumpulan data dan teknik analisis data yang dikembangkan oleh Weinberg, et. al. (2012). Peneliti menggunakan 2 teknik pengumpulan data, yaitu:

\section{a. Wawancara}

Wawancara ini bermaksud untuk menggali informasi dari segi konteks yang mana pembaca menggunakan tiap bagian buku teks. Untuk mencapai hal itu, diturunkan beberapa tujuan dan situasi kondisi selama mahasiswa menggunakan buku teks. Beberapa tujuan yang berpotensi menjadi alasan ketika menggunakan tiap bagian buku teks di antaranya membaca untuk pemahaman, memahami dan memeriksa definisi dan teorema, meringkas teks, membaca tugas untuk melihat ide yang paling sering muncul, menggunakan jawaban latihan untuk memeriksa tugas, menggunakan soal dan jawaban latihan yang ekstra untuk memeriksa pemahaman dari soal yang diberikan, membaca atau menyalin tugas untuk melengkapi tugas dan mencari jawaban tanpa pemecahan 
masalah. Sedangkan situasi yang mana mahasiswa menggunakan buku teks di luar kelas perkuliahan di antaranya persiapan sebelum perkuliahan, mengerjakan tugas dan belajar saat menghadapi ujian.

Wawancara direkam (audiorecorded) dan dicatat.

b. Angket

Angket untuk surveiberisi tentang laporan mahasiswa mengenai bagian buku teks apa yang mereka gunakan, kapan buku teks digunakan dan apa tujuan buku teks digunakan. Juga terdapat pertanyaan yang mengarah pada bagaimana buku teks digunakan di perkuliahan dan apa karakteristik yang mahasiswa nilai dalam buku teks matematika.

c. Observasi

Observasi dalam penelitian ini dilakukan pada saat perkuliahan di kelas. Observasi dilakukan selama minggu ke-9 setelah UTS. Hal yang diamati adalah bagaimana mahasiswa menggunakan buku teks dan bagian mana yang digunakan pada buku teks.

Hal lain yang perlu diperhatikan dalam observasi adalah apakah peneliti mempengaruhi situasi kelas saat perkuliahan. Karena "situasi alami" saat proses perkuliahan di kelas dapat terganggu oleh kehadiran peneliti (Leder and Forgasz, 2002). Maka observasi harus di-setting secara alami seperti perkuliahan biasa. Randahl (2012) menyarankan bahwa dalam observasi, agar situasi kelas dibuat sealami mungkin, peneliti menyampaikan ke kelas bahwa kehadiran peneliti untuk mengetahui situasi kelas secara umum, misalnya untuk mengetahui kesulitan yang dialami mahasiswa dalam pembelajaran matematika.

Pada penelitian ini menggunakan teknik analisisstatistika deskriptif dan nonparametrik.

1. Teknik analisis statistika deskriptif untuk menentukan ukuran pemusatan data. Hasil statistik ini disajikan dalam tabel dan grafik.

2. Teknik analisis statistika nonparametrik yang digunakan adalah

a. Uji McNemar, yaitu untuk menentukan apakah terdapat perbedaan antara dua sampel yang berpasangan dengan mensyaratkan bahwa data harus nominal. Misal membandingkan persentase mahasiswa yang melaporkan penggunaan tiap komponen buku teks.

b. Uji Cochran's Q, yaitu sama dengan uji McNemar, namun untuk tiga atau lebih sampel berpasangan. Misal membandingkan laporan penggunaan buku teks mahasiswa dari berbagai macam komponen buku teks.

Semua pengujian hipotesis menggunakan hipotesis tak berarah (non-directional null hypothesis)

Sumber data dalam penelitian ini berasal dari berbagai sumber, yaitu dari hasil angket, wawancara dan observasi. Desain penelitiandalam menganalisis data dari berbagai sumber dapat digunakan analisis 
triangulasi. Hal ini penting dalam mempertimbangkan bagaimana data dikumpulkan dari setiap pendapat yang satu dengan pendapat yang lain, baik pendapat tersebut sama atau kontradiksi (Golden, 2006).

\section{HASIL DAN PEMBAHASAN}

\section{Hasil}

Pada subbab ini akan disajikan rangkuman hasil survei. Mahasiswa yang berpartisipasi, yaitu yang mengembalikan angket, sebanyak 63 orang. Mata kuliah dan jumlah mahasiswa dirangkum pada tabel 1 .

Tabel. 1

Mata Kuliah dan Jumlah Mahasiswa

\begin{tabular}{lcc}
\hline \multicolumn{1}{c}{$\begin{array}{c}\text { Mata } \\
\text { kuliah }\end{array}$} & $\begin{array}{c}\text { Tingkat/Kel } \\
\text { as }\end{array}$ & $\begin{array}{c}\text { Mahasisw } \\
\text { a }\end{array}$ \\
\hline Kalkulus 2 & I/A & 33 \\
\hline $\begin{array}{l}\text { Struktur } \\
\text { Aljabar }\end{array}$ & II/A & 30 \\
\hline $\begin{array}{l}\text { Statistika } \\
\text { Matematik } \\
\text { a }\end{array}$ & III/A & 15 \\
\hline
\end{tabular}

Sebagai survei awal, mahasiswa ditanya apakah mereka memiliki buku teks sendiri, memiliki bersama teman, meminjam, menggunakan catatan dari dosen atau tidak memiliki buku teks. Hasil survei ditunjukkan pada tabel di bawah.

Tabel. 2

Kepemilikan Buku Teks

\begin{tabular}{lc}
\hline Kepemilikan & Persentase \\
\hline $\begin{array}{l}\text { Memiliki } \\
\text { buku teks } \\
\text { sendiri }\end{array}$ & 65,1 \\
\hline $\begin{array}{l}\text { Memiliki } \\
\text { bersama } \\
\text { teman }\end{array}$ & 11,1 \\
\hline Meminjam & 7,9 \\
\hline $\begin{array}{l}\text { Tidak } \\
\text { memiliki }\end{array}$ & 15,9 \\
buku teks & \\
\hline
\end{tabular}

Dari tabel di atas, sebagian besar mahasiswa memiliki buku teks. Namun, masih ada beberapa mahasiswa yang belum memiliki buku teks, yang persentasenya lebih besar dari mahasiswa yang memiliki buku teks bersama teman dan yang meminjam.Rangkuman penggunaan tiap komponen dari buku teks mahasiswa ditunjukkan pada tabel di bawah.

Tabel. 3

Presentase Mahasiswa yang Menggunakan tiap Komponen Buku Teks

\begin{tabular}{lc}
\hline \multicolumn{1}{c}{ Komponen } & Persentase Mahasiswa \\
\hline Bab Pendahuluan & 42,9 \\
\hline Bab Penjelasan & 71,4 \\
\hline Contoh & 81 \\
\hline Bab Ringkasan & 33,3 \\
\hline Latihan Soal & 74,6 \\
\hline Jawaban Soal & 44,4 \\
\hline
\end{tabular}

Perbedaan penggunaan tiap $=6-1=5$ dan $\alpha=0,05$ diperoleh komponen seperti ditunjukkan Tabel $3 \quad \mathrm{Q}(5)=74,346, \mathrm{p}<0,05$. Hasil ini diuji dengan uji Q Cochran. Dengan df dibandingkan dengan $\chi^{2}=11,07$ 
untuk $\mathrm{df}=5$ dan $\alpha=0,05$. Diperoleh bahwa $\mathrm{Q}(5)>\chi^{2}$. Artinya terdapat perbedaan yang signifikan dalam penggunaan tiap komponen buku teks. Terutama penggunaan komponen $\mathrm{Bab}$ Ringkasan secara signifikan lebih kecil dari komponen-komponen yang lain.

Selanjutnya, membandingkan

untuk persentase mahasiswa yang melaporkan penggunaan tiap komponen diuji dengan uji McNemar. Hasil uji ini ditunjukkan pada tabel 4.4. Dengan menggunakan Bonferroni-adjusted alpha-level sebesar 0,0033, terdapat 9 pasang komponen yang signifikan dan 6 pasang komponen yang tidak signifikan.

Tabel 4

Hasil uji McNemar untuk komponen yang berpasangan

\begin{tabular}{lcl}
\hline \multicolumn{1}{c}{ Pasangan antarkomponen } & $p$ & Keterangan \\
\hline Pendahuluan \& Penjelasan Teks &, 000 & berbeda signifikan $(p<0,05)$ \\
\hline Pendahuluan \& Contoh &, 000 & berbeda signifikan $(p<0,05)$ \\
\hline Pendahuluan \& Ringkasan &, 286 & tidak berbeda $(p=0,286)$ \\
\hline Pendahuluan \& Soal-soal &, 000 & berbeda signifikan $(p<0,05)$ \\
\hline Pendahuluan \& Jawaban Soal Latihan & 1,000 & tidak berbeda $(p=1,000)$ \\
\hline Penjelasan Teks \& Contoh &, 109 & tidak berbeda $(p=0,109)$ \\
\hline Penjelasan Teks \& Ringkasan &, 000 & berbeda signifikan $(p<0,05)$ \\
\hline Penjelasan Teks \& Soal-soal &, 791 & tidak berbeda $(p=0,791)$ \\
\hline Penjelasan Teks \& Jawaban Soal Latihan &, 003 & berbeda signifikan $(p<0,05)$ \\
\hline Contoh \& Ringkasan &, 000 & berbeda signifikan $(p<0,05)$ \\
\hline Contoh \& Soal-soal &, 125 & tidak berbeda $(p=0,125)$ \\
\hline Contoh \& Jawaban Soal Latihan &, 000 & berbeda signifikan $(p<0,05)$ \\
\hline Ringkasan \& Soal-soal &, 000 & berbeda signifikan $(p<0,05)$ \\
\hline Ringkasan \& Jawaban Soal Latihan &, 167 & tidak berbeda $(p=0,167)$ \\
\hline Soal-soal \& Jawaban Soal Latihan &, 000 & berbeda signifikan $(p<0,05)$ \\
\hline
\end{tabular}

Untuk tiap komponen, terdapat kelas mahasiswa yang mempunyai persentase yang tinggi. Seperti ditunjukkan pada Tabel 5, untuk mahasiswa tingkat 2 dan 3, menggunakan komponen Contoh hampir semua mahasiswa, sedangkan untuk tingkat 1 , menggunakan $\mathrm{Bab}$
Penjelasan Teks lebih dari setengah jumlah mahasiswa kelas tersebut. Walaupun, penggunaan tiap tingkat mahasiswa berbeda, tetapi tidak terdapat kelas pada setiap tingkat yang secara konsisten menggunakan komponen buku teks yang lebih tinggi dari kelas tingkat yang lain. 
Tabel 5

Penggunaan Komponen Buku Teks pada Setiap Tingkat

\begin{tabular}{lrrr}
\hline \multirow{2}{*}{ Komponen } & \multicolumn{3}{c}{ Mahasiswa } \\
\cline { 2 - 4 } & Tingkat 1 & Tingkat 2 & Tingkat 3 \\
\hline Bab Pendahuluan & 25,9 & 44,0 & 81,8 \\
\hline Bab Penjelasan Teks & 63,0 & 76,0 & 81,8 \\
\hline Contoh & 55,6 & 100,0 & 100,0 \\
\hline Ringkasan & 25,9 & 52,0 & 9,1 \\
\hline Soal-soal & 44,4 & 96,0 & 100,0 \\
\hline Jawaban Soal Latihan & 33,3 & 60,0 & 36,4
\end{tabular}

1. Bab Pendahuluan dan Penjelasan Teks

Mahasiswa yang membaca Bab Pendahuluan dan Penjelasan Teks lebih banyak saat mengerjakan tugas daripada saat persiapan kuliah dan saat menghadapi ujian. Seperti ditunjukkan Tabel 6 dan tabel 7 .

Tabel 6

Penggunaan Bab Pendahuluan

\begin{tabular}{lrrrr}
\hline Waktu membaca & $\begin{array}{c}\text { Saat Persiapan } \\
\text { untuk Kuliah }\end{array}$ & $\begin{array}{c}\text { Saat } \\
\text { Mengerjakan } \\
\text { Tugas }\end{array}$ & $\begin{array}{c}\text { Saat Belajar } \\
\text { untuk Ujian }\end{array}$ & $\begin{array}{c}\text { Waktu } \\
\text { Lain }\end{array}$ \\
\hline Persentase & 27,5 & 37,5 & 20,0 & 15,0 \\
\hline
\end{tabular}

Tabel 7

Penggunaan Bab Penjelasan Teks

\begin{tabular}{lcrrr}
\hline Waktu membaca & $\begin{array}{c}\text { Saat Persiapan } \\
\text { untuk Kuliah }\end{array}$ & $\begin{array}{c}\text { Saat } \\
\text { Mengerjakan } \\
\text { Tugas }\end{array}$ & $\begin{array}{c}\text { Saat Belajar } \\
\text { untuk Ujian }\end{array}$ & $\begin{array}{c}\text { Waktu } \\
\text { Lain }\end{array}$ \\
\hline Persentase & 29,7 & 37,6 & 20,6 & 12,1 \\
\hline
\end{tabular}

Selain itu, di antara mahasiswa yang membaca Bab Pendahuluan dan Penjelasan Teks, paling banyak adalah "Membaca untuk pemahaman", seperti ditunjukkan Tabel 4.8 dan 4.9.
Tabel 8

Alasan Membaca Bab Pendahuluan

\begin{tabular}{lr}
\hline \multicolumn{1}{c}{ Alasan membaca } & Persentase \\
\hline Membaca untuk pemahaman & 100,0 \\
\hline $\begin{array}{l}\text { Mengerti definisi dan } \\
\text { teorema }\end{array}$ & 96,3 \\
\hline $\begin{array}{l}\text { Mengerti definisi dan } \\
\text { teorema }\end{array}$ & 81,5 \\
\hline Merangkum teks & 77,8 \\
\hline Alasan Lain & 40,7 \\
\hline
\end{tabular}


Tabel 9

\begin{tabular}{lr}
\multicolumn{2}{|c}{ Alasan Membaca Bab Penjelasan Teks } \\
\hline \multicolumn{1}{c}{ Alasan membaca } & Persentase \\
\hline $\begin{array}{l}\text { Membaca untuk } \\
\text { pemahaman }\end{array}$ & 88,9 \\
\hline $\begin{array}{l}\text { Melihat definisi dan } \\
\text { teorema }\end{array}$ & 80,0 \\
\hline $\begin{array}{l}\text { Mengerti definisi dan } \\
\text { teorema }\end{array}$ & 66,7 \\
\hline Merangkum teks & 77,8 \\
\hline Alasan Lain & 33,3 \\
\hline
\end{tabular}

Data pada Tabel 6 dan Tabel 8 diambil dari 27 mahasiswa yang memilih menggunakan Bab Pendahuluan dan data pada Tabel. 7 dan tabel 9 diambil dari 45 mahasiswa yang memilih menggunakan Bab Penjelasan Teks.

2. Contoh

Mahasiswa yang melaporkan penggunaan Contoh lebih banyak daripada komponen-komponen yang lain, seperti yang ditunjukkan Tabel 3. Penggunaan Contoh oleh mahasiswa terutama saat mengerjakan tugas. Dan juga, sedikit lebih banyak saat belajar untuk ujian daripada saat persiapan untuk kuliah, seperti ditunjukkan Tabel 10.

Tabel 10

Penggunaan Bab Contoh

\begin{tabular}{lcccc}
\hline Waktu membaca & $\begin{array}{c}\text { Saat Persiapan } \\
\text { untuk Kuliah }\end{array}$ & $\begin{array}{c}\text { Saat } \\
\text { Mengerjakan } \\
\text { Tugas }\end{array}$ & $\begin{array}{c}\text { Saat Belajar } \\
\text { untuk Ujian }\end{array}$ & $\begin{array}{c}\text { Waktu } \\
\text { Lain }\end{array}$ \\
\hline
\end{tabular}

\begin{tabular}{lrrrr}
\hline Persentase & 24,3 & 38,2 & 25,7 & 11,8
\end{tabular}

Kemudian, alasan paling banyak di antara mahasiswa yang menggunakan Contoh, yaitu sebanyak 51 orang, adalah untuk membaca untuk pemahaman, seperti ditunjukkan pada Tabel 11.

\section{Tabel 11}

Alasan Membaca Contoh

\begin{tabular}{|c|c|}
\hline Alasan membaca & Persentase \\
\hline $\begin{array}{l}\text { Membaca untuk } \\
\text { pemahaman }\end{array}$ & 88,2 \\
\hline $\begin{array}{l}\text { Mengerti definisi dan } \\
\text { teorema }\end{array}$ & 76,5 \\
\hline Merangkum teks & 70,6 \\
\hline Alasan Lain & 29,4 \\
\hline
\end{tabular}

Perbedaan alasan penggunaan Contoh seperti ditunjukkan Tabel 11 diuji dengan uji Q Cochran. Dengan df $=4$
$-1=3$ dan $\alpha=0,05$ diperoleh $\mathrm{Q}(3)=$ 53,296, $\mathrm{p}<0,05$. Hasil ini dibandingkan dengan $\chi^{2}=7,815$ untuk df $=3$ dan $\alpha=0,05$. Diperoleh bahwa $\mathrm{Q}(3)>\chi^{2}$. Artinya terdapat perbedaan yang signifikan dalam alasan penggunaan Contoh.

Selanjutnya, untuk membandingkan persentase mahasiswa yang melaporkan penggunaan Contoh berdasarkan alasan diuji dengan uji McNemar. Hasil uji ini ditunjukkan pada Tabel 12. Dengan menggunakan Bonferroniadjusted alpha-level sebesar 0,0083, terdapat 4 pasang alasan yang signifikan dan 2 pasang alasan yang tidak signifikan. 
Tabel 12

Hasil uji McNemar untuk alasan yang berpasangan

\begin{tabular}{lcc}
\hline \multicolumn{1}{c}{ Pasangan antaralasan } & $p$ & Keterangan \\
\hline $\begin{array}{l}\text { Membaca untuk Pemahaman\&Mengerti } \\
\text { definisi dan Teorema }\end{array}$ &, 180 & tidak berbeda $(p=0,180)$ \\
\hline $\begin{array}{l}\text { Membaca untuk } \\
\text { Pemahaman\&Merangkum Teks }\end{array}$ &, 004 & berbeda signifikan $(p<0,05)$ \\
\hline $\begin{array}{l}\text { Membaca untuk Pemahaman\&Alasan } \\
\text { Lain }\end{array}$ &, 000 & berbeda signifikan $(p<0,05)$ \\
\hline $\begin{array}{l}\text { Mengerti Definisi dan } \\
\text { Teorema\&Merangkum Teks }\end{array}$ &, 375 & tidak berbeda $(p=0,375)$ \\
\hline $\begin{array}{l}\text { Mengerti Definisi dan Teorema\&Alasan } \\
\text { Lain }\end{array}$ &, 000 & berbeda signifikan $(p<0,05)$ \\
\hline Merangkum Teks \&Alasan Lain &, 000 & berbeda signifikan $(p<0,05)$ \\
\hline
\end{tabular}

3. Soal-soal dan Jawaban Latihan

mengerjakan tugas, seperti Mahasiswa banyak ditunjukkan Tabel 13. Sedangkan menggunakan soal-soal. Namun, untuk penggunaan jawaban latihan, sedikit menggunakan jawaban latihan. mahasiswa banyak yang jarang atau Paling banyak mahasiswa tidak pernah menggunakannya, seperti menggunakan soal-soal saat terlihat pada Tabel 14.

Tabel 13

Penggunaan Soal-soal

\begin{tabular}{lcrrr}
\hline Waktu membaca & $\begin{array}{c}\text { Saat Persiapan } \\
\text { untuk Kuliah }\end{array}$ & $\begin{array}{c}\text { Saat } \\
\text { Mengerjakan } \\
\text { Tugas }\end{array}$ & $\begin{array}{c}\text { Saat Belajar } \\
\text { untuk Ujian }\end{array}$ & $\begin{array}{c}\text { Waktu } \\
\text { Lain }\end{array}$ \\
\hline Persentase & 21,2 & 44,2 & 20,2 & 14,4 \\
\hline
\end{tabular}

Tabel 14

Penggunaan Jawaban Latihan

\begin{tabular}{lrrr}
\hline Frekuensi & $\begin{array}{c}\text { Tidak pernah } \\
\text { atau jarang }\end{array}$ & Kadang & $\begin{array}{c}\text { Sering atau } \\
\text { selalu }\end{array}$ \\
\hline Persentase & 38,6 & 35,1 & 26,4 \\
\hline
\end{tabular}

Dari tabel 15, mahasiswa mahasiswa yang melaporkan kebanyakan menggunakan soal-soal penggunaan soal berdasarkan alasan yaitu untuk membaca untuk diuji dengan uji McNemar. Hasil uji memahami ide apa yang paling sering ini ditunjukkan pada Tabel 16. Dengan muncul.Perbandingan persentase menggunakan Bonferroni-adjusted 
alpha-level sebesar 0,0167, terdapat 2 pasang alasan yang tidak signifikan. pasang alasan yang signifikan dan 1

Tabel 15

Alasan Penggunaan Soal-soal

\begin{tabular}{lr}
\hline \multicolumn{1}{c}{ Alasan menggunakan soal-soal } & Persentase \\
\hline Membaca untuk memahami ide apa yang paling sering muncul & 85,1 \\
\hline Membaca/menyalin untuk melengkapi tugas & 76,6 \\
\hline Alasan lain & 36,2 \\
\hline
\end{tabular}

Tabel 16

Hasil uji McNemar untuk alasan yang berpasangan

\begin{tabular}{|c|c|c|c|}
\hline Pasangan antaralasan & $p$ & \multicolumn{2}{|c|}{ Keterangan } \\
\hline $\begin{array}{l}\text { Membaca untuk memahami ide apa yang } \\
\text { paling sering muncul\&Membaca/menyalin } \\
\text { untuk melengkapi tugas }\end{array}$ & \multicolumn{3}{|c|}{,424 tidak berbeda $(p=0,424)$} \\
\hline $\begin{array}{l}\text { Membaca untuk memahami ide apa yang } \\
\text { paling sering muncul\&Alasan Lain }\end{array}$ & \multicolumn{3}{|c|}{,000 berbeda signifikan $(p<0,05)$} \\
\hline $\begin{array}{l}\text { Membaca/menyalin untuk melengkapi } \\
\text { tugas\&Alasan Lain }\end{array}$ & \multicolumn{3}{|c|}{, 000 berbeda signifikan $(p<0,05)$} \\
\hline $\begin{array}{l}\text { Sedangkan pada penggunaan } \\
\text { jawaban latihan, kebanyakan untuk } \\
\text { memeriksa kebenaran tugas yang }\end{array}$ & \multicolumn{3}{|c|}{$\begin{array}{c}\text { alasan yang signifikan dan } 4 \text { pasang } \\
\text { alasan yang tidak signifikan. } \\
\text { Tabel } \mathbf{1 7} \\
\text { Alasan Penggunaan Jawaban Latihan }\end{array}$} \\
\hline $\begin{array}{l}\text { dikerjakan. Seperti ditunjukkan pada } \\
\text { Tabel 17. Perbandingan persentase }\end{array}$ & \multicolumn{3}{|c|}{ Alasan menggunakan } \\
\hline mahasiswa yang melaporkan & Cek tuga & s saya & 75,0 \\
\hline $\begin{array}{lrr}\text { penggunaan } & \text { jawaban latihan } \\
\text { berdasarkan alasan diuji dengan uji }\end{array}$ & \multicolumn{3}{|c|}{$\begin{array}{l}\text { Cek pemahaman saya } \\
\text { tentang soal yang tidak }\end{array}$} \\
\hline McNemar. Hasil uji ini ditunjukkan & ditugask & & 50,0 \\
\hline $\begin{array}{l}\text { pada Tabel 18. Dengan menggunakan } \\
\text { Bonferroni-adjusted alpha-level }\end{array}$ & \multicolumn{3}{|c|}{ Mencari jawaban tanpa } \\
\hline sebesar 0,0083 , terdapat 2 pasang & Alasan la & & 21,4 \\
\hline
\end{tabular}


Tabel 18

Hasil uji McNemar untuk alasan yang berpasangan

\begin{tabular}{lcc}
\hline \multicolumn{1}{c}{ Pasangan antaralasan } & $p$ & Keterangan \\
\hline $\begin{array}{l}\text { Cek tugas saya\&Cek pemahaman saya tentang } \\
\text { soal yang tidak ditugaskan }\end{array}$ &, 065 & tidak berbeda $(p=0,065)$ \\
\hline $\begin{array}{l}\text { Cek tugas saya\&Mencari jawaban tanpa } \\
\text { mengerjakan soal }\end{array}$ &, 039 & tidak berbeda $(p=0,039)$ \\
\hline Cek tugas saya\&Alasan Lain &, 000 & berbeda signifikan $(p<0,05)$ \\
\hline $\begin{array}{l}\text { Cek pemahaman saya tentang soal yang tidak } \\
\text { ditugaskan\&Mencari jawaban tanpa } \\
\text { mengerjakan soal }\end{array}$ & 1,000 & tidak berbeda $(p=1,000)$ \\
\hline $\begin{array}{l}\text { Cek pemahaman saya tentang soal yang tidak } \\
\text { ditugaskan\& Alasan Lain }\end{array}$ &, 008 & berbeda signifikan $(p<0,05)$ \\
\hline $\begin{array}{l}\text { Mencari jawaban tanpa mengerjakan soal\& } \\
\text { Alasan Lain }\end{array}$ &, 016 & tidak berbeda $(p=0,016)$ \\
\hline
\end{tabular}

Hasil survei terkait kesulitan yang dihadapi mahasiswa saat menggunakan buku teks dirangkum pada tabel 19. Kesulitan dalam hal memahami definisi dan mengerjakan soal dihadapi sebagian besar mahasiswa. Kesulitan berikutnya yang banyak dihadapi mahasiswa adalah memahami konsep dasar permasalahan.

Tabel 19

Kesulitan dalam menggunakan buku teks

\begin{tabular}{lr}
\hline \multicolumn{1}{c}{ Kesulitan } & Persentase \\
\hline Memahami simbol/notasi & 13,4 \\
\hline Memahami definisi/teorema & 30,4 \\
\hline $\begin{array}{l}\text { Memahami konsep dasar } \\
\text { permasalahan }\end{array}$ & 19,6 \\
\hline Mengerjakan soal & 30,4 \\
\hline Lainnya & 2,7 \\
\hline
\end{tabular}

\section{Pembahasan}

Berdasarkan kepemilikan buku teks, mahasiswa masih banyak yang tidak memiliki buku teks. Hal ini menunjukkan kesadaran mereka untuk menjadi pembelajar mandiri masih kurang. Referensi materi yang mereka peroleh hanya dari catatan dan penjelasan dosen di kelas.

Komponen-komponen teks yang terdapat dalam buku teks, dirancang untuk mengatur kemajuan pembaca dalam memahami materi melalui teks tersebut. Terutama bab pendahuluan dan penjelasan teks. Akan tetapi, Mahasiswa cenderung mengabaikan untuk membaca pendahuluan dan penjelasan teks. Lebih lagi, mahasiswa kebanyakan melaporkan penggunaan buku teks saat mengerjakan tugas atau mempersiapkan ujian, bukan untuk mempersiapkan materi agar lebih paham saat perkuliahan di kelas. Walaupun pada beberapa komponen, mahasiswa melaporkan penggunaannya saat persiapan untuk kuliah, namun ketika survei dengan wawancara, mereka banyak yang menyatakan bahwa penggunaan buku teks kebanyakan saat mengerjakan 
tugas atau saat akan menghadapi ujian.

Mahasiswa

cenderung menggunakan bab contoh untuk meningkatkan pemahamannya. Banyak mahasiswa juga melaporkan menggunakan soal-soal untuk memahami ide apa yang paling sering muncul dan menggunakan jawaban latihan untuk memahami materi. Hal ini menunjukkan bahwa mahasiswa menganggap bahwa mempelajari contoh, soal-soal dan jawabannya merupakan metode agar memahami mata kuliah yang diambil.

Dari data survei menunjukkan bahwa terdapat ketidaksesuaian antara tujuan mahasiswa dan usaha mereka untuk memperoleh pemahaman. Dari alasan mereka menggunakan tiap komponen, kebanyakan mereka menyatakan bahwa membaca komponen tersebut untuk memahami materi, akan tetapi mereka mengabaikan menggunakan penjelasan teks materi sebagaimana penulis gunakan sebagai usaha untuk mengembangkan pemahaman materi. Ketidaksesuaian ini terjadi mungkin karena pemahaman mahasiswa tentang matematika. Mereka beranggapan bahwa matematika adalah kumpulan rumus yang harus dihafal dan digunakan (Schoenfeld, 1992).

Berdasarkan laporan mahasiswa mengenai kesulitan yang dihadapi dalam menggunakan buku teks, mereka kesulitan dalam memahami definisi/teorema dan dalam mengerjakan soal-soal. Sedikitnya mahasiswa yang menggunakan bab pendahuluan dan penjelasan bisa karena mereka kesulitan ketika memahami definisi atau teorema. Karena konsep dasar definisi dan teorema sulit untuk mereka pahami, maka mereka mengalami kesulitan dalam mengerjakan soal.

\section{KESIMPULAN DAN SARAN Kesimpulan \\ Berdasarkan hasil dan} pembahasan di atas, dapat diperoleh beberapa kesimpulan di antaranya mahasiswa cenderung menggunakan buku teks pada bagian yang memudahkan mereka mengerjakan soal-soal. Kebanyakan mereka menggunakan bab contoh. Selain itu, terdapat ketidaksesuaian antara tujuan mahasiswa menggunakan buku teks, yaitu memperoleh pemahaman dengan usaha mereka untuk menguasai materi.Mahasiswa kesulitan untuk memahami konsep dasar seperti definisi dan teorema yang mengakibatkan kesulitan dalam mengerjakan soal.

\section{Saran}

Saran untuk mahasiswa yaitu mereka harus mengubah metode membaca buku teks agar pemahaman materi yang diperoleh lebih utuh. Kemudian bahwa dosenmempunyai peranan penting untuk memberi masukan kepada mahasiswa dalam menggunakan buku teks.

\section{DAFTAR PUSTAKA}

Afolabi, S. S. \& Animasahun, I. A.,2013, Mathematics Textbook 
Attributes As Predictor Of Students' Attitude To Mathematics, European Scientific Journal, 159 - 170.

Anton, H. \& Rorres, C., 2005, Elementary Linear Algebra, 9th edition, John Wiley \& Sons, Inc.

Eco, U., 1979, The Role of the Reader: Explorations in the Semiotics of Texts, Bloomington, IN: Indiana University Press.

Golden, S. T., 2006, Observation in poverty research, Focus, 24(3), 29-32.

Johansson, M., 2005a, The mathematics textbook: from artefact to instrument. Nordic Studies in Mathematics Education, NOMAD, 10(3-4), 43-64.

Leder, G. C., \& Forgasz, H. J., 2002, Measuring mathematical beliefs and their inpact on the learning of mathematics: A new approach. In G. Leder, E. Pehkonen, \& G. Toerner (Eds.), Mathematical beliefs and their impact on teaching and learning of mathematics (pp. 95-113), Dordrecht, The Netherlands: Kluwer Academic Publishers.

Lloyd, G. M., and S. Behm, 2002, The Impact of Prospective Elementary Teachers' Experiences with ReformOriented Mathematics Curriculum Materials. Paper presented at Annual Meeting of the American

EducationalResearch

Association. April 1-5, 2002, New Orleans, LA.
Love, E., and D. Pimm, 1996, 'This is so': A text on texts. In International Handbook of Mathematics Education (pp. 371-409), eds. A. Bishops, K.Clements, C. Keitel, et al. Dordrecht, The Netherlands: Kluwer AcademicPublishing. (Trans.).

Pedoman Akademik Universitas Kuningan Tahun 2015 - 2016.

Randahl, M., 2012, First-year engineering students' use of their mathematics textbookOpportunities and constraints,Mathematics

Education ResearchJournal, 24, 239-256.

Sastre Vazquez, P., D'Andrea R., Villacampa, Y., Navarro Gonzalez, F. J., 2013, Do firstyear University students understand the language of Mathematics?, Proceedings of the $3 r d$ world conference on learning, teaching and educational leadership (pp. 1658 - 1662).

Schoenfeld, A. 1992. Learning to think mathematically: Problem solving, metacognition, and sense making in mathematics. In Handbookof Research on Mathematics Teaching and Learning (pp. 334-370), D. Grouws (ed.). New York: Macmillan.

Shepherd, M. D, 2005, Encouraging students to read mathematics. PRIMUS, 15, 124-144.

Stray, C. (1994). Paradigms regained: towards a historical sociology of 
the textbook. Journal of

Curriculum Studies, 26(1), 1-29.

Sugiyono, 2010, Metode Penelitian

Pendidikan: Pendekatan

Kuantitatif, Kualitatif dan R\&D,

Bandung: Penerbit Alfabeta.

Varberg, D., E. Purcell, and S. Rigdon, 2007, Calculus, 9th edition. Upper Saddle River, NJ: Pearson Education.

Weinberg, A., \& Wiesner, E., 2010, Understanding mathematics textbooks through readeroriented theory,Educational Studies in Mathematics, 76, 4663.

Weinberg, A., Wiesner, E., Benesh, B., \& Boester, T., 2012, Undergraduate students' selfreported use of mathematics textbooks. PRIMUS, 22(2), 152175. 
